\title{
Benzamides and Quinazolines from a Mangrove Actinomycetes Streptomyces sp. (No. 061316) and Their Inhibiting Caspase-3 Catalytic Activity in Vitro
}

\author{
Guodong Chen, ${ }^{a, \#}$ Hao GaO,${ }^{a, c, \#}$ Jinshan TAnG, ${ }^{a}$ Yuanfan Huang,${ }^{a}$ Ying Chen, ${ }^{a}$ Ying Wang, ${ }^{a}$ \\ Huinan Zhaо, ${ }^{a}$ Haipeng Lin, ${ }^{b}$ Qingyi XIE ${ }^{b}$ Kui Hong,${ }^{b}$ Jia LI, ${ }^{c}$ and Xinsheng YAO ${ }^{*, a}$ \\ ${ }^{a}$ Institute of Traditional Chinese Medicine and Natural Products, Jinan University College of Pharmacy/Guangdong \\ Province Key Laboratory of Pharmacodynamic Constituents of TCM and New Drugs Research, Jinan University; \\ Guangzhou 510632, People's Republic of China: ${ }^{b}$ Institute of Tropical Biosciences and Biotechnology, Chinese Academy \\ of Tropical Agriculture Sciences; Haikou 571101, P.R. China: and ${ }^{c}$ National Center for Drug Screening/State Key \\ Laboratory of Drug Research, Shanghai Institute of Materia Medica; Shanghai 201203, P. R. China.
}

Received November 17, 2010; accepted December 24, 2010; published online January 7, 2011

One new benzamide, 3-hydroxyl-2- $N$-iso-butyryl-anthranilamide (1), together with two known benzamides $(2,3)$ and three known quinazolines (4-6), was isolated from a mangrove actinomycetes Streptomyces sp. (No. 061316), which displayed inhibiting Caspase-3 activity in vitro. The structure of 1 was elucidated by electrospray ionization (ESI)-MS, NMR spectroscopies and X-ray crystal diffraction. After evaluation of all compounds for their inhibitory effect on Caspase-3 in vitro, 3-hydroxyl-anthranilamide (2) and 8-hydroxyl-2,4-dioxoquinazoline (6) showed activity against Caspase- 3 with $\mathrm{IC}_{50}$ values of 32 and $36 \mu \mathrm{M}$, respectively.

Key words Streptomyces sp.; benzamide; quinazoline; Caspase-3

Apoptosis, or programmed cell death, is a highly regulated biological process involved in maintaining normal tissue homeostasis. ${ }^{1)}$ However, deregulation of the apoptotic process can contribute to many human diseases, including neurodegenerative diseases (such as Alzheimer disease and Huntington disease), ischemic damage, autoimmune disorders, and several forms of cancer. ${ }^{2)}$ Caspase-3 is one of executioners in caspase-dependent apoptosis, and is activated in nearly every model of apoptosis, including those with different signaling pathways. ${ }^{3,4)}$ Furthermore, Caspase-3 is expressed in almost all tissues at relatively high levels and has high catalytic activity compared with other executioner caspases, so it has been seen as a promising therapeutic target, which received particular attention in finding its inhibitors. ${ }^{5}$ Both reversible and irreversible peptide-based inhibitors have been reported to be effective in animal models of stroke, myocardial ischemia/reperfusion injury, liver disease, and traumatic brain injury. ${ }^{6-8)}$ Research on Caspase-3 inhibitors can develop drugs against excessive apoptosis-related diseases. During investigation on bioactive components from microorganisms, one $\mathrm{MeOH}$ extract of a mangrove actinomycetes Streptomyces sp. (No. 061316) showed inhibition of Caspase- 3 with $\mathrm{IC}_{50}$ value of $5.2 \pm 0.9 \mathrm{mg} / \mathrm{ml}$. 16S RNA analysis identified the producing organism as Streptomyces sp. (Genbank accession no. GU980133). With the help of various chromatographic methods, one new compound, 3-hydroxyl2- $N$-iso-butyryl-anthranilamide (1), was isolated from the mangrove actinomycetes Streptomyces sp. (No. 061316), along with five known compounds 3-hydroxyl-anthranilamide (2), anthranilamide (3), ${ }^{9}$ 8-hydroxly-4(3H)-quinazoline (4), 8-hydroxyl-2-methyl-4(3H)-quinazoline (5) and 8hydroxyl-2,4-dioxoquinazoline (6). Herein, the identification and characterization of compounds from Streptomyces sp. (No. 061316) were described in this paper, as well as their inhibitory effect on Caspase-3 in vitro.

\section{Results and Discussion}

The strain (No. 061316) was isolated from a mangrove soil sample collected at Wenchang, and was identified to belong to Streptomyces by the $16 \mathrm{~S}$ ribosomal RNA (rRNA) gene sequence analysis result and its morphological and cell wall chemical components (e.g., the highest 16S rRNA gene sequence similarity was similar to Streptomyces tanashiensis LMG $20274^{\mathrm{T}}$ at $99.385 \%$ with $9 \mathrm{nt}$ difference at $1463 \mathrm{nt}$; aerial mycelia developed well, long and ranged in color from white to grey on yeast extract-malt extract (ISP2) medium; it contained diaminopimelic acids (DAP) as cell wall amino acid). The strain was cultured with FM3 media at $28^{\circ} \mathrm{C}$ for $7 \mathrm{~d}$, and the fermentation broth was concentrated to brown gum, and refluxed three times with $\mathrm{MeOH}$. After filtration and evaporation of the solvent in vacuo, the crude extract was diluted with $\mathrm{H}_{2} \mathrm{O}$ and then successively partitioned with cyclohexane and chloroform. The Caspase-3 bioassays showed that the chloroform extract (C) and aqueous residue (W) displayed inhibition on Caspase- 3 with $\mathrm{IC}_{50}$ value of $2.3 \pm 1.0$ and $3.2 \pm 0.7 \mu \mathrm{g} / \mathrm{ml}$, respectively. The chloroform extract was subjected to silica gel column chromatography and preparative HPLC to yield $1(3.4 \mathrm{mg})$. The aqueous residue (W) was subjected to macroporous resin HP20 to yield 3 fractions (W0, W1 and W2). Then fraction W1 was separated by column chromatography over octadecyl silane chemically bonded to silica gel (ODS), sephadex LH20, HW40 and preparative HPLC to yield $2(69 \mathrm{mg}), 3(4.2 \mathrm{mg})$, 4 (3.0 mg), 5 (17.4 mg) and 6 (2.9 mg).

3-Hydroxyl-2- $N$-iso-butyryl-anthranilamide (1) was obtained as colorless needles $(\mathrm{MeOH})$; its molecular formula was established as $\mathrm{C}_{11} \mathrm{H}_{14} \mathrm{~N}_{2} \mathrm{O}_{3}$ according to the $[\mathrm{M}-\mathrm{H}]^{-}$at $\mathrm{m} / \mathrm{z} 221.0939$ (Calcd for $\mathrm{C}_{11} \mathrm{H}_{13} \mathrm{~N}_{2} \mathrm{O}_{3}, 221.0932$ ) in high resolution-electrospray ionization-mass spectra (HR-ESI-MS). The ${ }^{1} \mathrm{H}-\mathrm{NMR}$ data of $\mathbf{1}$ (Table 1) showed the presence of four exchangeable protons $\left(\delta_{\mathrm{H}} 11.32,9.98,6.16,5.71\right) ; \delta_{\mathrm{H}} 7.19$ $(1 \mathrm{H}, \mathrm{dd}, J=7.8,1.8 \mathrm{~Hz}), 7.14(1 \mathrm{H}$, pseudo $\mathrm{t}, J=7.8 \mathrm{~Hz})$ and $7.10(1 \mathrm{H}, \mathrm{dd}, J=7.8,1.8 \mathrm{~Hz})$ showed the presence of a $1,2,3-$ 
Table $1 .{ }^{13} \mathrm{C}-\mathrm{NMR}(100 \mathrm{MHz})$ and ${ }^{1} \mathrm{H}-\mathrm{NMR}(400 \mathrm{MHz})$ Data of Compound $\mathbf{1}$ and Key Signals of HMBC

\begin{tabular}{|c|c|c|c|c|c|}
\hline \multirow{2}{*}{ Position } & \multicolumn{5}{|c|}{1} \\
\hline & $\delta_{\mathrm{C}}{ }^{a)} \mathrm{mult}$ & $\left.\delta_{\mathrm{H}}(J \text { in Hz})^{a}\right)$ & $\delta_{\mathrm{C}}{ }^{b)} \mathrm{mult}$ & $\delta_{\mathrm{H}}(J \text { in } \mathrm{Hz})^{b)}$ & HMBC \\
\hline 1 & & & $123.3, \mathrm{~s}$ & & \\
\hline 2 & 124.6, s & & $127.4, \mathrm{~s}$ & & \\
\hline 3 & $151.1, \mathrm{~s}$ & & $150.8, \mathrm{~s}$ & & \\
\hline 4 & $119.9, \mathrm{~d}$ & $7.00(\mathrm{dd}, 6.7,2.9)$ & $124.4, \mathrm{~d}$ & $7.19(\mathrm{dd}, 7.8,1.8)$ & C- 2,6 \\
\hline 5 & $126.1, \mathrm{~d}$ & 7.12 (m, overlap) & $126.1, \mathrm{~d}$ & 7.14 (pseudo t, 7.8) & $\mathrm{C}-1,3$ \\
\hline 6 & $119.3, \mathrm{~d}$ & 7.12 (m, overlap) & $119.0, \mathrm{~d}$ & $7.10(\mathrm{dd}, 7.8,1.8)$ & $\mathrm{C}-2,4$ \\
\hline 7 & $169.9, \mathrm{~s}$ & & $171.4, \mathrm{~s}$ & & \\
\hline 8 & $177.0, \mathrm{~s}$ & & 178.6, s & & \\
\hline 9 & $34.7, \mathrm{~d}$ & $2.66(\mathrm{sep}, 6.8)$ & $36.5, \mathrm{~d}$ & $2.72(\mathrm{sep}, 6.8)$ & \\
\hline 9-C $\underline{\mathrm{H}}_{3}$ & $19.3, \mathrm{q}$ & $1.14(\mathrm{~d}, 6.8)$ & $19.6, \mathrm{q}$ & $1.30(\mathrm{~d}, 6.8)$ & C-8, 9 \\
\hline$-\mathrm{CON} \underline{\mathrm{H}}_{\mathrm{a}}$ & & $7.81(\mathrm{brs})$ & & $6.16(\mathrm{brs})$ & \\
\hline$-\mathrm{CON} \underline{\mathrm{H}}_{\mathrm{b}}$ & & 7.55 (br s) & & $5.71(\mathrm{brs})$ & \\
\hline $\operatorname{ArN\underline {H}}$ & & & & 11.32 (brs) & \\
\hline$-\mathrm{O} \underline{\mathrm{H}}$ & & & & 9.98 (br s) & $\mathrm{C}-3,4$ \\
\hline
\end{tabular}

a) Measured in DMSO- $d_{6}$. b) Measured in $\mathrm{CDCl}_{3}$.

three substituted phenyl skeleton in $1 ; \delta_{\mathrm{H}} 2.72(1 \mathrm{H}$, sep, $J=6.8 \mathrm{~Hz}$ ) and 1.30 (each $3 \mathrm{H}, \mathrm{d}, J=6.8 \mathrm{~Hz}$ ) suggested that there was a geminal dimethyl group in 1 . The ${ }^{13} \mathrm{C}-\mathrm{NMR}$ spectrum of 1 combined with the DEPT-135 spectrum displayed 10 signals, but 11 carbons were shown to be contained from its molecular formula (two of carbons were chemical equivalence): five quaternary carbons (three of quaternary carbons bonded to oxygen or nitrogen), four methines and two chemically equivalent methyl groups.

The heteronuclear multiple bond correlation (HMBC) signal found at $\delta_{\mathrm{H}} 9.98(-\mathrm{OH}) / \delta_{\mathrm{C}} 124.4(\mathrm{C}-4)$ indicated that the hydroxyl group should be attached to $\mathrm{C}-3$, combining the signals of $\delta_{\mathrm{H}} 7.14(\mathrm{H}-5) / \delta_{\mathrm{C}} 150.8(\mathrm{C}-3)$ and $\delta_{\mathrm{H}} 9.98$ $(-\mathrm{OH}) / \delta_{\mathrm{C}} 150.8(\mathrm{C}-3)$. On the other hand, the HMBC correlation from $\delta_{\mathrm{H}} 1.30\left(9-\mathrm{C}_{3}\right)$ to $\delta_{\mathrm{C}} 178.6(\mathrm{C}-8)$ revealed the connection of the geminal dimethyl group to $\mathrm{C}-8$ in $\mathbf{1}$. These data in conjunction with molecular formula indicated the planar structure of $\mathbf{1}$ as shown in Fig. 1. Furthermore, 1-CO may form hydrogen bond with $2-\mathrm{N} \underline{H}$ in solution, according to the chemical shift value of exchangeable proton $\left(\delta_{\mathrm{H}} 11.32\right.$ in $\mathrm{CDCl}_{3}, \delta_{\mathrm{H}} 10.37$ in DMSO- $\left.d_{6}\right)$. Because the bond between nitrogen and carbon in $-\mathrm{N}-\mathrm{CO}-$ can not rotate freely, the two protons in 7- $\mathrm{N}_{2}$ were not chemical equivalence. The X-ray crystal diffraction analysis (Fig. 2) allowed the determination of the structure of $\mathbf{1}$.

3-Hydroxyl-anthranilamide (2) was obtained as red needles $(\mathrm{MeOH})$; its molecular formula was determined as $\mathrm{C}_{7} \mathrm{H}_{8} \mathrm{~N}_{2} \mathrm{O}_{2}$ according to the $[\mathrm{M}-\mathrm{H}]^{-}$at $m / z 151.0510$ (Calcd for $\mathrm{C}_{7} \mathrm{H}_{7} \mathrm{~N}_{2} \mathrm{O}_{2}, 151.0513$ ) in HR-ESI-MS. The ${ }^{1} \mathrm{H}-\mathrm{NMR}$ data of 2 (Table 2) showed the presence of four exchangeable protons $\left(\delta_{\mathrm{H}} 9.38,7.64,7.00,6.05\right) ; \delta_{\mathrm{H}} 7.07(1 \mathrm{H}, \mathrm{d}, J=7.9 \mathrm{~Hz})$, $6.75(1 \mathrm{H}, \mathrm{d}, J=7.9 \mathrm{~Hz})$ and $6.36(1 \mathrm{H}$, pseudo t, $J=7.9 \mathrm{~Hz})$ showed the presence of a 1,2,3-three substituted phenyl group in $2 .{ }^{13} \mathrm{C}$-NMR data of $\mathbf{2}$ (Table 2) showed four quaternary carbons (two of quaternary carbons bonded to oxygen or nitrogen) and three methines.

The HMBC correlations found at $\delta_{\mathrm{H}} 6.36(\mathrm{H}-5) / \delta_{\mathrm{C}} 114.1$ $(\mathrm{C}-1)$ and $\delta_{\mathrm{H}} 7.07(\mathrm{H}-6) / \delta_{\mathrm{C}} 171.4(\mathrm{C}-7)$ suggested that an amido group was attached to $\mathrm{C}-1$, while a hydroxyl group was bonded to C-3 according to the HMBC correlations of $\delta_{\mathrm{H}} 6.36(\mathrm{H}-5) / \delta_{\mathrm{C}} 144.6(\mathrm{C}-3), \delta_{\mathrm{H}} 6.75(\mathrm{H}-6) / \delta_{\mathrm{C}} 139.4(\mathrm{C}-2)$ and $\delta_{\mathrm{H}} 9.38(-\mathrm{OH}) / \delta_{\mathrm{C}} 139.4(\mathrm{C}-2)$. These data in conjunc-

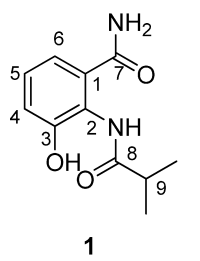<smiles>NC(=O)c1ccccc1O</smiles><smiles>NC(=O)c1ccccc1N</smiles>
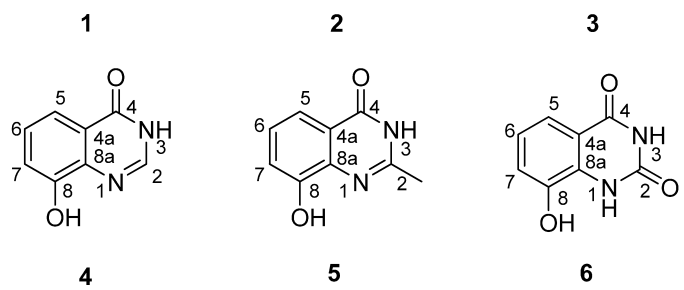

Fig. 1. Structures of $1-6$

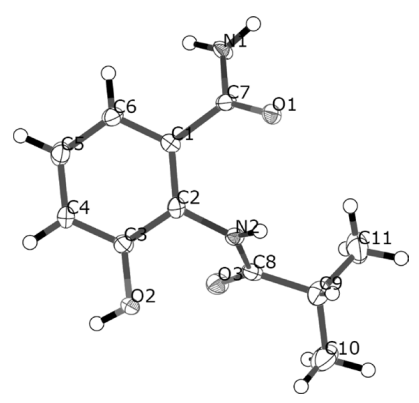

Fig. 2. ORTEP Drawing of 3-Hydroxyl-2- $N$-iso-butyryl-anthranilamide (1)

tion with molecular formula indicated the planar structure of 2 as shown in Fig. 1. 2 was determined as 3-hydroxyl-anthranilamide, which was usually synthetic in the past ${ }^{10)}$ and was first time in being from nature in this report.

8-Hydroxyl-2,4-dioxoquinazoline (6) was obtained as white amorphous powder; its molecular formula was determined as $\mathrm{C}_{8} \mathrm{H}_{6} \mathrm{~N}_{2} \mathrm{O}_{3}$ according to the $[\mathrm{M}-\mathrm{H}]^{-}$at $\mathrm{m} / \mathrm{z}$ 177.0313 (Calcd for $\mathrm{C}_{8} \mathrm{H}_{5} \mathrm{~N}_{2} \mathrm{O}_{3}, 177.0306$ ) in HR-ESI-MS. ${ }^{1} \mathrm{H}-\mathrm{NMR}$ data of 6 (Table 3) showed the presence of three exchangeable protons $\left(\delta_{\mathrm{H}} 11.18,10.27,10.27\right) ; \delta_{\mathrm{H}} 7.35(1 \mathrm{H}$, dd, $J=7.8,1.2 \mathrm{~Hz}), 7.07(1 \mathrm{H}, \mathrm{dd}, J=7.8,1.2 \mathrm{~Hz})$ and 6.99 $(1 \mathrm{H}$, pseudo t, $J=7.8 \mathrm{~Hz})$ showed the presence of a $1,2,3$ three substituted phenyl skeleton in $\mathbf{6} \cdot{ }^{13} \mathrm{C}$-NMR data of $\mathbf{6}$ 
Table 2. ${ }^{13} \mathrm{C}-\mathrm{NMR}(100 \mathrm{MHz})$ and ${ }^{1} \mathrm{H}-\mathrm{NMR}\left(400 \mathrm{MHz}\right.$ ) Data of Compounds $\mathbf{2}, \mathbf{3}$ (in DMSO- $d_{6}$ )

\begin{tabular}{|c|c|c|c|c|c|}
\hline \multirow{2}{*}{ Position } & 2 & \multicolumn{4}{|c|}{3} \\
\hline & $\delta_{\mathrm{C}}$, mult. & $\delta_{\mathrm{H}}(J$ in $\mathrm{Hz})$ & HMBC & $\delta_{\mathrm{C}}$, mult. & $\delta_{\mathrm{H}}(J$ in $\mathrm{Hz})$ \\
\hline 1 & $114.1, \mathrm{~s}$ & & & $113.7, \mathrm{~s}$ & \\
\hline 2 & $139.4, \mathrm{~s}$ & & & $150.1, \mathrm{~s}$ & \\
\hline 3 & $144.6, \mathrm{~s}$ & & & 114.3, d & $6.67(\mathrm{dd}, 7.8,1.3)$ \\
\hline 4 & $115.5, \mathrm{~d}$ & $6.75(\mathrm{~d}, 7.9)$ & C-2, 6 & $131.8, \mathrm{~d}$ & 7.12 (pseudo td, $7.8,1.3$ ) \\
\hline 5 & $113.9, \mathrm{~d}$ & 6.36 (pseudo t, 7.9) & $\mathrm{C}-1,3$ & $116.3, \mathrm{~d}$ & 6.47 (pseudo td, $7.8,1.3$ ) \\
\hline 6 & $119.2, \mathrm{~d}$ & $7.07(\mathrm{~d}, 7.9)$ & C- $2,4,7$ & $128.7, \mathrm{~d}$ & $7.52(\mathrm{dd}, 7.8,1.3)$ \\
\hline 7 & $171.4, \mathrm{~s}$ & & & $171.3, \mathrm{~s}$ & \\
\hline$-\mathrm{CON} \underline{\mathrm{H}}_{\mathrm{a}}$ & & 7.64 (brs) & & & 7.68 (brs) \\
\hline$-\mathrm{CON}_{\mathrm{b}}$ & & 7.00 (brs) & & & 7.01 (brs) \\
\hline $\mathrm{ArN}_{2}$ & & $6.05(\mathrm{brs})$ & & & $6.53(\mathrm{brs})$ \\
\hline$-\mathrm{OH}$ & & $9.38(\mathrm{brs})$ & $\mathrm{C}-2$ & & \\
\hline
\end{tabular}

Table 3. ${ }^{13} \mathrm{C}-\mathrm{NMR}(100 \mathrm{MHz})$ and ${ }^{1} \mathrm{H}-\mathrm{NMR}(400 \mathrm{MHz})$ Data of Compounds 4, 5, 6 and Key Signals of HMBC (in DMSO- $d_{6}$ )

\begin{tabular}{|c|c|c|c|c|c|c|c|c|c|}
\hline \multirow{2}{*}{ Position } & \multicolumn{3}{|c|}{4} & \multicolumn{3}{|c|}{5} & \multicolumn{3}{|c|}{6} \\
\hline & $\delta_{\mathrm{C}}$, mult. & $\delta_{\mathrm{H}}(J$ in $\mathrm{Hz})$ & HMBC & $\delta_{\mathrm{C}}$, mult. & $\delta_{\mathrm{H}}(J$ in $\mathrm{Hz})$ & HMBC & $\delta_{\mathrm{C}}$, mult. & $\delta_{\mathrm{H}}(J$ in $\mathrm{Hz})$ & HMBC \\
\hline $1-\mathrm{N} \underline{\mathrm{H}}$ & & & & & & & & 11.18 (brs) & \\
\hline $2^{-}$ & $143.4, \mathrm{~d}$ & $8.04(\mathrm{~s})$ & $\mathrm{C}-4,8 \mathrm{a}$ & $152.5, \mathrm{~s}$ & & & $149.8, \mathrm{~s}$ & & \\
\hline $3-\mathrm{NH}$ & & $12.20(\mathrm{brs})$ & & & $12.11(\mathrm{brs})$ & C- $4 a$ & & 10.27 (brs) & \\
\hline 4 & $160.7, \mathrm{~s}$ & & & $161.6, \mathrm{~s}$ & & & $162.8, \mathrm{~s}$ & & \\
\hline 5 & $115.5, \mathrm{~d}$ & $7.54(\mathrm{dd}, 8.0,1.4)$ & $\mathrm{C}-4,7,8 \mathrm{a}$ & $115.4, \mathrm{~d}$ & $7.50(\mathrm{dd}, 8.0,1.2)$ & $\mathrm{C}-4,7,8 \mathrm{a}$ & 116.6, d & $7.35(\mathrm{dd}, 7.8,1.2)$ & $\mathrm{C}-4,7,8 \mathrm{a}$ \\
\hline 6 & 127.2, d & 7.32 (pseudo t, 8.0) & C- $-4 a, 8$ & $126.1, \mathrm{~d}$ & 7.24 (pseudo t, 8.0) & C- $-4 a, 8$ & $122.2, \mathrm{~d}$ & 6.99 (pseudo t, 7.8) & C- $4 \mathrm{a}, 8$ \\
\hline 7 & $118.3, \mathrm{~d}$ & $7.18(\mathrm{dd}, 8.0,1.4)$ & $C-5,8 \mathrm{a}$ & $118.0, \mathrm{~d}$ & $7.15(\mathrm{dd}, 8.0,1.2)$ & $C-5,8 a$ & $118.9, \mathrm{~d}$ & $7.07(\mathrm{dd}, 7.8,1.2)$ & $C-5,8 a$ \\
\hline 8 & $152.9, \mathrm{~s}$ & & & $152.2, \mathrm{~s}$ & & & $144.2, \mathrm{~s}$ & & \\
\hline $4 a$ & $123.4, \mathrm{~s}$ & & & $121.4, \mathrm{~s}$ & & & $115.3, \mathrm{~s}$ & & \\
\hline $8 \mathrm{a}$ & $137.6, \mathrm{~s}$ & & & $137.9, \mathrm{~s}$ & & & $130.1, \mathrm{~s}$ & & \\
\hline $\mathrm{CH}_{3}$ & - & - & $21.3, \mathrm{q}$ & $2.37(\mathrm{~s})$ & & $\mathrm{C}-2$ & - & - & \\
\hline$-\mathrm{OH}$ & & 9.68 (brs) & & & 9.33 (brs) & & & 10.27 (brs) & \\
\hline
\end{tabular}

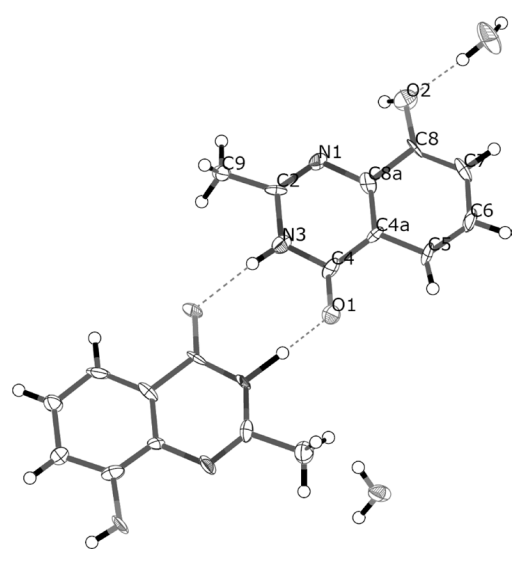

Fig. 3. ORTEP Drawing of 8-Hydroxyl-2-methyl-4(3H)-quinazoline (5)

(Table 3) displayed five quaternary carbons (three of quaternary carbons bonded to oxygen or nitrogen) and three methines. These signals suggested that $\mathbf{6}$ possessed the same phenyl group as in 8-hydroxyl-2-methyl-4(3H)-quinazoline (5). This deduction was confirmed by HMBC analysis. These data in conjunction with molecular formula and comparing with ${ }^{1} \mathrm{H}$-NMR data of 8-hydroxyl-2,4-dioxoquinazoline ${ }^{11)}$ indicated the planar structure of $\mathbf{6}$ as shown in Fig. 1.6 was determined as 8-hydroxyl-2,4-dioxoquinazoline, which was firstly discovered from the nature.

All the isolated compounds were examined for their inhibitory effect on Caspase-3 in vitro. 2 and $\mathbf{6}$ showed inhibitory effect on Caspase- 3 with $\mathrm{IC}_{50}$ values of $32 \pm 7$ and $36 \pm 7 \mu \mathrm{M}$, respectively. $\mathbf{1}, \mathbf{3}-\mathbf{5}$ did not show any significant inhibitory activity, and both had $\mathrm{IC}_{50}$ values greater than $100 \mu \mathrm{M}$. Ac-DEVD-CHO, which was a selective peptide inhibitor of Caspase- 3 and competitively inhibits Caspase- 3 by binding to the catalytic active site, ${ }^{2)}$ was prepared as a positive control in this assay. Although $\mathbf{2}$ and $\mathbf{6}$ were not effective as Ac-DEVD-CHO (24 $\pm 2 \mathrm{~nm})$ in vitro, their effect on Caspase-3 was close to reported small molecular Caspase-3 inhibitors from nature (such as F03ZA-673A, ${ }^{12)}$ which was from metabolites of a Dematiaceae fungi, also have ability to inhibit the activation of Caspase- 3 with $\mathrm{IC}_{50}$ value of $21 \mu \mathrm{m}$ ).

Some peptide-based Casapse-3 inhibitors are effective in vitro such as Ac-DEVD-CHO, but the pharmacokinetics of these inhibitors prevents their use in clinical environments. Small molecules that inhibit Caspase- 3 activity would be valuable for treatment of diseases involving excessive cell death. ${ }^{13)}$ Most Skeletons of small-molecule inhibitors against Caspase-3 were $N$-nitrosoanilines, dithiocarbamate, isatin sulfonamide and quinolines, but benzamides have not been ever reported. Furthermore, most of benzamides and quinazolines, especially 2 and 6, were artificial..$^{-11,14)}$ Therefore, the isolation of compounds from Streptomyces sp. (No. 061316) not only provided another approach to obtaining benzamides and quinazolines, but also may offer new source in finding Caspase-3 inhibitor. 


\section{Experimental}

General UV spectra were recorded on a JASCO V-550 UV/vis spectrometer. IR spectra were recorded on a JASCO FT/IR-480 plus spectrometer. ESI-IT-MS spectra were performed on a Finnigan LCQ Advantage MAX mass spectrometer and HR-ESI-MS spectra were obtained on a Micromass Q-time-of-flight (TOF) and an Agilent 6210 LC/MSD TOF mass spectrometers. NMR spectra were measured on a Bruker AV 400 (equipped with a $5 \mathrm{~mm}$ broad band observe (BBO) z-gradient probe) at $400 \mathrm{MHz}$ for ${ }^{1} \mathrm{H}$ - and $100 \mathrm{MHz}$ for ${ }^{13} \mathrm{C}$-NMR assignments were made by using ${ }^{1} \mathrm{H},{ }^{13} \mathrm{C}$, correlation spectroscopy (COSY), distortionless enhancement by polarization transfer (DEPT), heteronuclear single quantum coherence (HSQC), and HMBC experiments. Chemical shifts were given in $\delta(\mathrm{ppm})$ with the solvent signals as an internal standard. The analytical HPLC was performed on a Welch Materials XB-C18 column $(4.6 \times 250 \mathrm{~mm}, 5 \mu \mathrm{m})$ and a HPLC system, equipped with a Dionex Ultimate 3000 pump, a Dionex Ultimate 3000 diode array detector (DAD), a Dionex Ultimate 3000 Column Compartment, a Dionex U1timate 3000 autosampler (Dionex, U.S.A.) and a Alltech (Grace) 2000ES evaporative light scattering detector (ELSD) (Alltech, U.S.A.). The preparative HPLC was carried on a Welch Materials XB-C18 column $(21.2 \times 250 \mathrm{~mm}, 5 \mu \mathrm{m})$ and a VARIAN Prostar 210 , equipped with UV detectors (U.S.A.). Column chromatography was carried out on silica gel (200-300 mesh) (Qingdao Haiyang Chemical Group Corp., Qingdao, China), Sephadex LH-20 (Pharmacia), HW40 (Toyopearl), Diaion HP 20 (Mitsubishi) and ODS $(60-80 \mu \mathrm{m}, \mathrm{YMC})$, respectively. Silica gel GF254 (Qingdao Haiyang Chemical Group Corp., Qingdao, China).

Actinomycetes Material The Streptomyces sp. strain (No. 061316) was isolated from mangrove soils at Wenchang $\left(\mathrm{N}^{\circ} 9^{\circ} 36.506^{\prime}, \mathrm{E} 110^{\circ} 47.746^{\prime}\right)$, Hainan province, P. R. China, on Gause No. 1 medium (soluble starch $1 \mathrm{~g} / \mathrm{l}$, casein $0.03 \mathrm{~g} / 1, \mathrm{NaCl} 0.5 \mathrm{~g} / 1, \mathrm{~K}_{2} \mathrm{HPO}_{4}, 0.5 \mathrm{~g} / 1, \quad \mathrm{MgSO}_{4} \cdot 7 \mathrm{H}_{2} \mathrm{O}, 0.5 \mathrm{~g} / \mathrm{l}$, $\mathrm{FeSO}_{4} \cdot 7 \mathrm{H}_{2} \mathrm{O}, 0.01 \mathrm{~g} / 1$, agar $20 \mathrm{~g} / 1, \mathrm{pH} 7.2$ - 7.4). The strain was grown on ISP2 medium (yeast extract $4 \mathrm{~g} / 1$, malt extract $10 \mathrm{~g} / 1$, glucose $4 \mathrm{~g} / 1$, agar $20 \mathrm{~g} / \mathrm{l}, \mathrm{pH} 7.2-7.4$ ) at $28^{\circ} \mathrm{C}$ for $7 \mathrm{~d}$. Biomass was obtained from the ISP2 culture for cell wall amino acid analysis and $16 \mathrm{~S}$ rRNA sequencing analysis. Amino acid of whole-cell hydrolysates were analyzed by thin layer chromatography (TLC) as described by Hasegawa et al. ${ }^{15}$ Genomic DNA preparation, PCR amplification and sequencing of the 16S rRNA gene were carried out using procedure described as Hong et al. ${ }^{16)}$ The values for pairwise $16 \mathrm{~S}$ rRNA gene sequence similarity among the closest strains were determined using the EzTaxon server (http://www.Eztaxon.org). ${ }^{17}$ ) A voucher specimen was deposited at the China Center for Type Culture Collection, Wuhan, P. R. China (CCTCC M209152). The GenBank accession number was GU980133

Fermentation, Extraction and Isolation The strain (No. 061316) was cultured in $500 \mathrm{ml}$ shake-flasks with FM3 media (soluble starch $(20 \mathrm{~g} / \mathrm{l}$ ), soybean extract $(15 \mathrm{~g} / 1)$, yeast powder $(5 \mathrm{~g} / 1)$, peptone $(2 \mathrm{~g} / 1), \mathrm{CaCO}_{3}(4 \mathrm{~g} / \mathrm{l})$, sea salt $(18 \mathrm{~g} / \mathrm{l}) ; \mathrm{pH} 7.0)$ at $28^{\circ} \mathrm{C}$ for $7 \mathrm{~d}$.

The fermentation broth of strain (No.061316) was concentrated to brown gum, and refluxed three times with $51 \mathrm{MeOH}$ at $70^{\circ} \mathrm{C}$ for $1 \mathrm{~h}$. After filtration and evaporation of the solvent in vacuo, the crude extract $(904.5 \mathrm{~g})$ was diluted with $\mathrm{H}_{2} \mathrm{O}$ and then successively partitioned with cyclohexane and chloroform three times with the same volume. After solvent removed, the crude extract was divided into cyclohexane extract (A, $10.1 \mathrm{~g})$, chloroform extract (C, $3.1 \mathrm{~g})$ and aqueous residue (W, $836.7 \mathrm{~g}$ ). The Caspase-3 bioassays showed that the chloroform extract $(\mathrm{C})$ and aqueous residue $(\mathrm{W})$ displayed inhibition on Caspase- 3 with $\mathrm{IC}_{50}$ value of $2.3 \pm 1.0$ and $3.2 \pm 0.7 \mu \mathrm{g} / \mathrm{ml}$, respectively. The chloroform extract (C, $3.1 \mathrm{~g})$ was subjected to silica gel column chromatography, eluted with a cyclohexane-ethyl acetate gradient $(100: 0,98: 2,70: 30,0: 100$ and $\mathrm{MeOH})$ to yield 5 fractions $(\mathrm{C} 1,13.7 \mathrm{mg}$; C2, $191.8 \mathrm{mg}$; C3, $69.7 \mathrm{mg}$; C4, $283.2 \mathrm{mg}$; C5, $946.5 \mathrm{mg}$ ). The fraction C4 was isolated by preparative HPLC with $\mathrm{MeOH}: \mathrm{H}_{2} \mathrm{O}(50: 50$, v/v), repeatedly, and then yield $1(3.4 \mathrm{mg})$. The aqueous residue (W) was subjected to macroporous resin $\mathrm{HP} 20$, eluted with a $\mathrm{H}_{2} \mathrm{O}-\mathrm{MeOH}$ gradient $(100: 0,50: 50$ and $0: 100, \mathrm{v} / \mathrm{v}$ ) to yield 3 fractions (W0, 747.8 g; W1, $23.8 \mathrm{~g} ; \mathrm{W} 2,4.4 \mathrm{~g}$ ). Then fraction W1 (23.8 g) was separated by ODS column chromatography, eluted with a gradient of increasing $\mathrm{MeOH}\left(5-100 \%\right.$, v/v) in $\mathrm{H}_{2} \mathrm{O}$ to afford seven subfractions $(\mathrm{W} 1 \mathrm{a}-\mathrm{g})$. Subfraction W1a $(15.1 \mathrm{~g})$ was separated by sephadex LH20 using $100 \% \mathrm{H}_{2} \mathrm{O}$ to yield $2(69 \mathrm{mg})$. Subfraction W1b $(1.91 \mathrm{~g})$ was separated by $\mathrm{HW} 40$ with a gradient of increasing $\mathrm{MeOH}(0-$ $50 \%, \mathrm{v} / \mathrm{v})$ in $\mathrm{H}_{2} \mathrm{O}$ to yield 6 (2.9 mg). Subfraction W1c (1.16 g) was separated by $\mathrm{HW} 40$ with a gradient of increasing $\mathrm{MeOH}\left(0-50 \%\right.$, v/v) in $\mathrm{H}_{2} \mathrm{O}$, and then purified by RP-HPLC using $\mathrm{MeOH}: \mathrm{H}_{2} \mathrm{O}(25: 75, \mathrm{v} / \mathrm{v})$ to yield 3 $(4.2 \mathrm{mg})$. Subfraction W1d $(1.10 \mathrm{~g})$ was separated by HW40 with a gradient of increasing $\mathrm{MeOH}(0-50 \%, v / v)$ in $\mathrm{H}_{2} \mathrm{O}$, and then purified by RP-HPLC using $\mathrm{MeOH}: \mathrm{H}_{2} \mathrm{O}(30: 70, \mathrm{v} / \mathrm{v})$ to yield $4(3.0 \mathrm{mg})$. Subfraction W1e
(1.56 g) was separated by HW40 with a gradient of increasing $\mathrm{MeOH}(0-$ $50 \%, \mathrm{v} / \mathrm{v})$ in $\mathrm{H}_{2} \mathrm{O}$ to yield 5 (17.4 mg).

3-Hydroxyl-2- $N$-iso-butyryl-anthranilamide (1): Colorless needles $(\mathrm{MeOH}) ; \mathrm{UV}(\mathrm{MeOH}) \lambda_{\max }(\log \varepsilon) 245 \mathrm{~nm}(4.10), 316 \mathrm{~nm}(3.75) ; \mathrm{IR}(\mathrm{KBr})$ $V_{\max } 2920,1683,1618,1475,1451,1387,1230,761 \mathrm{~cm}^{-1} ;{ }^{1} \mathrm{H}-$ and ${ }^{13} \mathrm{C}-$ NMR data, see Table 1; ESI-MS $m / z 221[\mathrm{M}-\mathrm{H}]^{-}$; HR-ESI-MS $m / z$ $221.0939[\mathrm{M}-\mathrm{H}]^{-}$(Calcd for $\mathrm{C}_{11} \mathrm{H}_{13} \mathrm{~N}_{2} \mathrm{O}_{3}, 221.0932$ ).

3-Hydroxyl-anthranilamide (2): Red needles (MeOH); UV (MeOH) $\lambda_{\max }$ $(\log \varepsilon) 219 \mathrm{~nm}$ (4.38), 316 (3.68); IR (KBr) $v_{\max } 3415,3387,3219,1660$, $1627,1550,1407,1277,1206,1119,753 \mathrm{~cm}^{-1} ;{ }^{1} \mathrm{H}-$ and ${ }^{13} \mathrm{C}-\mathrm{NMR}$ data, see Table 2; ESI-MS $m / z 153[\mathrm{M}+\mathrm{H}]^{+}, m / z 151[\mathrm{M}-\mathrm{H}]^{-}$; HR-ESI-MS $m / z$ $151.0510[\mathrm{M}-\mathrm{H}]^{-}$(Calcd for $\left.\mathrm{C}_{7} \mathrm{H}_{7} \mathrm{~N}_{2} \mathrm{O}_{2}, 151.0513\right)$.

Anthranilamide (3): Colorless needles $(\mathrm{MeOH}) ; \mathrm{UV}(\mathrm{MeOH}) \lambda_{\max }(\log \varepsilon)$ 206 (4.48), 238 (4.55), 281 (4.24), 318 (4.14) nm; IR (KBr) $v_{\max } 3411$, $3325,3192,1660,1627,1401,1315,1257,745 \mathrm{~cm}^{-1} ;{ }^{1} \mathrm{H}-$ and ${ }^{13} \mathrm{C}-\mathrm{mMR}$ data, see Table 2; ESI-MS $m / z 159[\mathrm{M}+\mathrm{Na}]^{-}, 295[2 \mathrm{M}+\mathrm{Na}]^{+}$; HR-ESI-MS $m / z 159.0526[\mathrm{M}+\mathrm{Na}]^{+}$(Calcd for $\left.\mathrm{C}_{7} \mathrm{H}_{8} \mathrm{~N}_{2} \mathrm{O}_{3} \mathrm{Na}, 159.0529\right)$.

8-Hydroxly-4(3H)-quinazoline (4): Colorless needles (MeOH); UV $(\mathrm{MeOH}) \lambda_{\max }(\log \varepsilon) 204$ (4.57), 238 (4.70), 284 (4.23), 316 (4.21) nm; IR (KBr) $v_{\max } 3411,3324,3179,1697,1656,1615,1577,1483,1453,1400$, 1349, 1296, 1234, $980 \mathrm{~cm}^{-1}$; ${ }^{1} \mathrm{H}-$ and ${ }^{13} \mathrm{C}-\mathrm{NMR}$ data, see Table 3; ESI-MS $m / z \quad 163[\mathrm{M}+\mathrm{H}]^{+}, 161[\mathrm{M}-\mathrm{H}]^{-}$; HR-ESI-MS m/z $163.0504[\mathrm{M}+\mathrm{H}]^{+}$ (Calcd for $\mathrm{C}_{8} \mathrm{H}_{7} \mathrm{~N}_{2} \mathrm{O}_{2}, 163.0502$ ).

8-Hydroxyl-2-methyl-4(3H)-quinazoline (5): Colorless needles $(\mathrm{MeOH})$; UV (MeOH) $\lambda_{\max }(\log \varepsilon) 206$ (4.10), 237 (4.23), 279 (3.84), 314 (3.75) nm; IR (KBr) $v_{\max } 3444,3047,2910,1677,1627,1578,1476,1306,1237,1065$, $757 \mathrm{~cm}^{-1}$; ${ }^{1} \mathrm{H}$ - and ${ }^{13} \mathrm{C}-\mathrm{NMR}$ data, see Table 3; ESI-MS $\mathrm{m} / \mathrm{z} 177[\mathrm{M}+\mathrm{H}]^{+}$, $199[\mathrm{M}+\mathrm{Na}]^{+}, 175[\mathrm{M}-\mathrm{H}]^{-}$; HR-ESI-MS m/z $175.0511[\mathrm{M}-\mathrm{H}]^{-}(\mathrm{Calcd}$ for $\mathrm{C}_{9} \mathrm{H}_{7} \mathrm{~N}_{2} \mathrm{O}_{2}, 175.0513$ ).

8-Hydroxyl-2,4-dioxoquinazoline (6): White amorphous powder; UV $(\mathrm{MeOH}) \lambda_{\max }(\log \varepsilon) 219(4.22), 235(4.24), 314(3.64) \mathrm{nm} ; \mathrm{IR}(\mathrm{KBr}) v_{\max }$ $3171,3101,1719,1659,1600,1515,1427,1320,1284,1179,742 \mathrm{~cm}^{-1} ;{ }^{1} \mathrm{H}-$ and ${ }^{13} \mathrm{C}-\mathrm{NMR}$ data, see Table 3; ESI-MS $m / z 177[\mathrm{M}-\mathrm{H}]^{-}, 355[2 \mathrm{M}-\mathrm{H}]^{-}$; HR-ESI-MS $m / z 177.0313[\mathrm{M}-\mathrm{H}]^{-}$(Calcd for $\mathrm{C}_{8} \mathrm{H}_{5} \mathrm{~N}_{2} \mathrm{O}_{3}, 177.0306$ ).

X-Ray Crystallographic Analysis of $1^{18)}$ Upon crystallization from $\mathrm{MeOH}$ using the vapor diffusion method, colorless crystals of $\mathbf{1}$ were obtained. Data were collected using a OXFORD CCD with a graphite monochromator and Mo $K \alpha$ radiation, $\lambda=0.71073 \AA$ at $150(2) \mathrm{K}$. Crystal data: $\mathrm{C}_{11} \mathrm{H}_{14} \mathrm{~N}_{2} \mathrm{O}_{3}, M=222.24$, space group monoclinic, $P 2{ }_{1} 2_{1} 2_{1}$; unit cell dimensions were determined to be $a=7.155(2) \AA, b=7.546(8) \AA, c=20.458(8) \AA$, $\alpha=90.00^{\circ}, \beta=90.00^{\circ}, \gamma=90.00^{\circ}, V=1104.5(12) \AA^{3}, Z=4, D x=1.337 \mathrm{mg} /$ $\mathrm{m}^{3}, F(000)=472, \mu(\mathrm{Mo} K \alpha)=0.098 \mathrm{~mm}^{-1} .2150$ unique reflections were collected to $\theta_{\max }=26.49^{\circ}$, in which 1918 reflections were observed $\left[F^{2}>\right.$ $\left.4 \sigma\left(F^{2}\right)\right]$. The structure was solved by direct methods using the SHELXS-97 program, and refined by the program SHELXL-97 and full-matrix leastsquares calculations. In the structure refinements, nonhydrogen atoms were placed on the geometrically ideal positions by the "ride on" method. Hydrogen atoms bonded to oxygen were located by the structure factors with isotropic temperature factors. The final refinement gave $R=0.0696, R w=$ 0.1771 , and $S=1.175$.

X-Ray Crystallographic Analysis of $5^{19)}$ Upon crystallization from $\mathrm{MeOH}$ using the vapor diffusion method, colorless crystals of $\mathbf{5}$ were obtained. Data were collected using a OXFORD CCD with a graphite monochromator and $\mathrm{Mo} K \alpha$ radiation, $\lambda=0.71073 \AA$ at $150(2) \mathrm{K}$. Crystal data: $\mathrm{C}_{9} \mathrm{H}_{8} \mathrm{~N}_{2} \mathrm{O}_{2}, M=176.17$, space group monoclinic, $P_{n}$; unit cell dimensions were determined to be $a=5.0458(3) \AA, b=25.0498(13) \AA, c=7.2978(5) \AA$, $\alpha=90.00^{\circ}, \beta=106.921(7)^{\circ}, \gamma=90.00^{\circ}, V=882.48(9) \AA^{3}, Z=4, D x=1.326$ $\mathrm{mg} / \mathrm{m}^{3}, F(000)=368, \mu(\mathrm{MoK} \alpha)=0.096 \mathrm{~mm}^{-1} .4020$ unique reflections were collected to $\theta_{\max }=30.17^{\circ}$, in which 2208 reflections were observed $\left[F^{2}>4 \sigma\left(F^{2}\right)\right]$. The structure was solved by direct methods using the SHELXS-97 program, and refined by the program SHELXL-97 and full-matrix least-squares calculations. In the structure refinements, nonhydrogen atoms were placed on the geometrically ideal positions by the "ride on" method. Hydrogen atoms bonded to oxygen were located by the structure factors with isotropic temperature factors. The final refinement gave $R=$ $0.0849, R w=0.0755$, and $S=0.809$.

Caspase-3 Enzymatic Assay and Inhibition of Catalytic Activity ${ }^{13}$ The enzymatic activity of Caspase- 3 at $35^{\circ} \mathrm{C}$ was determined by measuring the change in absorbance at $460 \mathrm{~nm}$ caused by the accumulation of pNA from hydrolysis of Ac-DEVD-pNA. A typical $100 \mu \mathrm{l}$ assay mixture contained 50 mм Hepes pH 7.5, $150 \mathrm{~mm} \mathrm{NaCl}, 1$ mm dithiothreitol, 1 mм EDTA, $100 \mu \mathrm{M}$ Ac-DEVD-pNA, and recombinant Caspase-3. Enzymatic activity was monitored continuously and the initial rate of hydrolysis was determined from the early linear region of the enzymatic reaction curve. 
Ac-DEVD-CHO solution was prepared as a positive control and inhibition assays were performed with $20 \mathrm{~nm}$ recombinant enzyme, $100 \mu \mathrm{m}$ Ac-DEVD-pNA in $50 \mathrm{~mm}$ Hepes pH 7.5, $150 \mathrm{~mm} \mathrm{NaCl}, 1 \mathrm{~mm}$ dithiothreitol, and $1 \mathrm{~mm}$ EDTA. Dilutions of inhibitors were based on estimated $\mathrm{IC}_{50}$ values. The $\mathrm{IC}_{50}$ was calculated from a nonlinear curve of percent inhibition vs. inhibitor concentration [I] using the equation, percentage inhibition= $100 /\left[1+\left(\mathrm{IC}_{50} /[\mathrm{I}]\right)^{k}\right]$, where $k$ is the Hill coefficient.

Acknowledgment We thank Doctor Herman Ho-Yung Sung (Department of Chemistry, The Hong Kong University of Science and Technology, Hong kong, China) for X-ray crystal diffraction analysis. This project was supported by grants from the National Natural Science Foundation of China (U0633008), the Ministry of Science and Technology of China (2009CB522300, 2008ZX09401-05 and 2009ZX09302-004), the Ministry of Education of China/Fok Ying Tung Education Foundation (121039), and State Key Laboratory of Drug Rearch (SIMM0812KF-02).

\section{References and Notes}

1) Ullman B. R., Aja T., Chen N., Diaz J. L., Gu X., Herrmann J., Kalish V. J., Karanewsky D. S., Kodandapani L., Krebs J. J., Linton S. D., Meduna S. P., Nalley K., Robinson E. D., Roggo S. P., Sayers R. O., Schmitz A., Ternansky R. J., Tomaselli K. J., Wu J. C., Bioorg. Med. Chem. Lett., 15, 3632-3636 (2005).

2) Howley B., Fearnhead H. O., J. Cell. Mol. Med., 12, 1502-1516 (2008).

3) Porter A. G., Janicke R. U., Cell Death Differ., 6, 99-104 (1999).

4) Mehmet H., Nature (London), 403, 29-30 (2000).

5) Scott C. W., Sobotka-Briner C., Wilkins D. E., Jacobs R. T., Folmer J. J., Frazee W. J., Bhat R. V., Ghanekar S. V., Aharony D., J. Pharmacol. Exp. Ther, 304, 433-440 (2003).

6) Yang W., Guastella J., Huang J. C., Wang Y., Zhang L., Xue D., Tran M., Woodward R., Kasibhatla S., Tseng B., Drewe J., Cai S. X., Br. J. Pharmacol., 140, 402-412(2003).
7) Garcia-Calvo M., Peterson E. P., Leiting B., Ruel R., Nicholson D. W. Thornberry N. A., J. Biol. Chem., 273, 32608-32613 (1998).

8) Cheng Y., Deshmukh M., D’Costa A., Demaro J. A., Gidday J. M., Shah A., Sun Y. L., Jacquin M. F., Johnson E. M., Holtzman D. M., J. Clin. Invest., 101, 1992-1999 (1998).

9) Roy A. D., Subramanian A., Roy R., J. Org. Chem., 71, 382-385 (2006).

10) D’Angeli F., Koski R. E., Henderson L. M., J. Biol. Chem., 214, 781787 (1955).

11) Hossain N., Ivanova S., Mensonides-Harsema M., US 2007/0123543 A1 (2007).

12) Ren X., Li S.-J., Dong Y.-S., Yang J.-S., Zhang H., Mu D., Lu X.-H., Zheng Z.-H., Lu M., He J.-G., Chin. Pharm. J., 42, 907-909 (2007).

13) Zhang Y.-H., Zhang H.-J., Wu F., Chen Y.-H., Ma X.-Q., Du J.-Q., Zhou Z.-L., Li J.-Y., Nan F.-J., Li J., FEBS J., 273, $4842-4852$ (2006).

14) Griffin R. J., Srinivasan S., Bowman K., Calvert A. H., Curtin N. J., Newell D. R., Pemberton L. C., Golding B. T., J. Med. Chem., 41, 5247-5256 (1998).

15) Hasegawa T., Takizawa M., Tanida S., J. Gen. Appl. Microbiol., 29, 319-322 (1983)

16) Hong K., Gao A.-H., Xie Q.-Y., Gao H., Zhuang L., Lin H.-P., Yu H.P., Li J., Yao X.-S., Goodfellow M., Ruan J.-S., Mar. Drugs, 7, $24-44$ (2009).

17) Chun J., Lee J. H., Jung Y., Kim M., Kim S., Kim B. K., Lim Y. W., Int. J. Syst. Evol. Microbiol., 57, 2259-2261 (2007).

18) The crystallographic data of $\mathbf{1}$ have been deposited with the Cambridge Crystallographic Data Centre as supplementary publication number CCDC 804262. Copies of the data can be obtained, free of charge, at http://www.ccdc.cam.ac.uk/data_request/cif.

19) The crystallographic data of $\mathbf{5}$ have been deposited with the Cambridge Crystallographic Data Centre as supplementary publication number CCDC 804263. Copies of the data can be obtained, free of charge, at http://www.ccdc.cam.ac.uk/data_request/cif. 